\title{
From Excerpt to Cosplay. Paths of Knowledge in the Nordic Museum Archive
}

\begin{abstract}
By
Simon Ekström

Abstract

The aim of this article is to shed some light on the situation that occurs when scholarly knowledge, once highly valued, is successively undermined, while elements of the same learning live on as attractive resources to other stakeholders. More accurately, the research question relates to the process that starts with many ethnologists who, over time, come to increasingly view formerly important materials as less relevant to their own academic issues. For the sake of the argument, the Nordic Museum's extensive collection of excerpts concerning folk customs and beliefs is used as an eye-opening case study. During the 1960s and 1970s, folklore researchers and ethnologists retreated from researching those lingering traces of the past-of which the Nordic Museum's excerpt collection constitutes a powerful material centre-and thus this field was left free for others to claim. By drawing attention to both the productive force of the Nordic Museum's collection of excerpts, and a number of contemporary and popular representations of ancient folklore, this article actualises a set of questions that deal with the relationship between new and old knowledge; for what becomes of previously sought after academic learning, once treasured in the Nordic Museum Archive, when the vast majority of the discipline heads for new materials, methods and theories?
\end{abstract}

Keywords: Archive, Excerpts, History of knowledge, Remediation, Nordic museum.

Ekström, Simon: "From Excerpt to Cosplay. Paths of Knowledge in the Nordic Museum Archive", Culture Unbound, Volume 12, issue 1, 2020: 116-140. Published by Linköping University Electronic Press: http://www.cultureunbound.ep.liu.se 


\section{Introduction: How to Become a Mermaid}

Just before Halloween 2016, the popular Swedish vlogger Therese Lindgren posted five videos on YouTube in one week, centring on the theme of Nordic Creatures. Described as tutorials, she outlines in detail how she dresses up as a mermaid, a forest nymph, a troll, a myling, and a tree sprite. However, these videos contain more than practical advice on foundation creams, eyeliner and hair gel. Each make-up session either begins or ends with Lindgren acting out the completed character on camera in a suitable natural setting. At the same time the forest nymph or troll is presented to the viewer, Lindgren's voice can be heard in the background as she, with great seriousness, explains some of the beliefs surrounding the creature in question.

At the beginning of the first video, in which Lindgren makes herself up into what she presents as a "seductive mermaid", the camera sweeps across a pile of books lit only by flickering candle light. One of the volumes is open to reveal a handwritten page. This is followed by Lindgren's suggestive characterisation. ${ }^{1}$ In translation, as the presentation is in Swedish, it goes like:

The Nordic mermaid is a powerful creature who rules over the water, the wind and the creatures of the sea. She can take on different forms, although most commonly she appears as a beautiful woman with long, flowing hair, which she can be seen sitting and combing at high tide. She normally demonstrates some fish-like features, such as gills, scales or a fish tail instead of legs. Handsome sailors run the risk of being lured down into the ocean by the mermaid, where they will live with her. However, those who refuse to heed the mermaid's call will feel her power and may find themselves aboard a sinking ship bound for the ocean floor.

Of course, one may well question how these tutorials should be viewed: Are they lingering folkloric relics in a digital age? Or are they a game of transitory identities in which Lindgren creatively borrows and combines elements from an older repertoire? Both questions are legitimate from an analytical perspective, but here I will test another point of entry. The intention of this article is to describe the dual movement whereby gathered knowledge is subjected to a critical process where scholarly value is successively undermined and downgraded while elements of the same learning live on as attractive resources in relation to both old and new stakeholders. Put differently, it is a matter of identifying the connections that join together the modern vlogger's YouTube performances with folklore research/ ethnology and the Nordic Museum as historically situated knowledge producers. 
As we will see, the search for the roots of these pedagogical videos leads us to the museum's bottom floor. It is here, in the section of the museum that includes the archive expedition, the library and the public reading room, that the extensive excerpt collection of folk beliefs and customs is stored. The collection is part of a larger corpus of material that constitutes the museum's Folklore Collection. The name is the result of a previous classification in which folklore researchers in the beginning of the twentieth century made a clear division between spiritual and material culture. Belief, custom and legend, like the fairy tales, were then attributed to so-called folklore. Other similar collections and archives were created in Sweden at the same time, most notably in Lund (1913), Uppsala (1914), and Gothenburg (1919).

The Nordic Museum's collection of excerpts contains large amounts of the past century's accumulated knowledge of the imaginative world that accommodated beings like water sprites, ghosts, gnomes, trolls and mermaids. Although knowledge always tends to change as it moves between different actors and media (cf. Bolter \& Grusin 1999), it is possible to establish a linkage between the already described stagings of various Nordic folklore characters on the digital platform of YouTube, and the considerably older excerpt collection. However, in doing so, we will also have to consider the fact that the majority of today's ethnologists and folklorists seldom make use of the original learning or forms of knowledge represented by the excerpts at the museum. By taking contemporary, non-academic, interpretations of old folklore as a point of departure, like the already mentioned performance on YouTube by Swedish vlogger Therese Lindgren, it becomes possible to relate these matters to a set of questions that deal with the relationship between new and old knowledge; for what becomes of previously accepted learning when the very scholarly point of it has migrated elsewhere? What possible lines of retreat and alternatives remain open to this older knowledge? And which new stakeholders will take over the stage that others, for various reasons, have left vacant?

\section{The Study of the Lingering}

Excerpt collections of various kinds have been created and stored in a wide range of archives. There is consequently considerable variation in how they are used as resources for both research and knowledge building. Therefore, before going any further with the subject, I would like to emphasize that the collection on which this article focuses is that which is associated with the Nordic Museum's Folklore Collection. Even though the article's discussion first and foremost applies to excerpts from the Folklore Collection, it might be of interest that the Nordic Museum's archive also keeps other excerpt collections that cover the presence of various material cultural products such as harrows, pepper mills or women's 
aprons. ${ }^{2}$ Needless to say, internationally, the use of excerpts has played a decisive role in many knowledge institutions (see Krajewski 2011).

The excerpts in the museum's Folklore Collection take up several cubic metres of space in the Nordic Museum's combined library and reading room. Overall, they can be described as isolated notes on some specific aspect of the themes of folk belief and custom that earlier museum staff and scholars have considered of interest at the time they were collected or sorted. In other words, these are saved excisions from larger wholes. The main habitats of the excerpts in question, what one might call their primary or original environments, were the theoretical schools of evolutionism and diffusionism, the former with roots in Romanticism and late nineteenth-century religious studies, the latter in the German theory of culture areas. In these settings the standpoints of the individual observation of folklore, whether still living or preserved in human memory, were made a perfect match with the greater theoretical context. When it comes to folk beliefs, this was expressed most clearly in what was known as the historical-cartographic method (or the Finnish school), in which the map was filled with dots that showed how a certain spiritual artefact manifested itself in geographical reality. ${ }^{3}$ For some decades, the dominant evolutionistic research interest steered towards seeking to reconstruct the most ancient types of myths, folk tales or customs and use, from which later variants had somehow departed. It was also deemed important to clarify cultural boundaries, pathways of dissemination and various types of relic-free areas, as well as the existence of survivals that had somehow resisted the work of time. Accordingly, those later tools and ambitions were the theoretical stands that all together constituted the diffusionistic program. ${ }^{4}$

In the introduction to Bygd och yttervärld (1942), Sigfrid Svensson, however, proposes a somewhat different method of approaching this old problem. He instead wants to know what happens when the novelty (in the form of innovation) comes to the countryside. How, as Svensson puts forward the question, does the new spread? How is it greeted and through which stakeholders and influencers is it assimilated? At the same time, in his own investigations, Svensson is actually just as interested in what causes resistance to the new, and the question of how and why the old is left behind. The studies in the book therefore deal with cultural meetings in which different layers of time stand against one another. For a period, whether long or brief, these periods coexist-sometimes resulting in combinations or hybrids-until the new finally gains the upper hand.

The discussion I intend to pursue is reminiscent of Svensson's initial question. I, too, am interested in change, disappearance and lingering as expressions of processes that may be viewed as both drawn-out and complex. However, the studies in Bygd och yttervärld are always based on what happens when something 
new appears on the scene-i.e. how novelties and innovations are received and disseminated or, on the contrary, discarded-while I primarily want to consider how the old continues to linger on. Transposed to the excerpts at the Nordic Museum, this means an interest in what happens as, over time, many ethnologists come to increasingly view these items as more or less irrelevant for their own academic issues.

The forthcoming discussion is then in theoretical debt to the interdisciplinary and constantly growing field of history of knowledge. It is common in these studies to highlight how older forms of knowledge are hybridised and associate themselves with other groups and interests (Secord 2004; Burke 2016; Östling \& Heidenblad 2017; see also Bäckman in this issue). This means that even established media, through which the previously recognised academic knowledge was preserved and communicated (e.g. literature, archives, excerpts, tables, maps, exhibitions and lectures), may be supplanted by or coexist with other, more disparate, forms of media (e.g. scholarly writing for a non-academic public, young adult fiction, and other fictional literature, as well as films, video games, live action role-playing, and cosplay). When knowledge is circulated between various stakeholders and audiences in this way, it is normally also re-mediated between genres and modes of presentations (Åhrén 2004; Gustavsson 2012; Gustavsson 2014:179ff; Jülich 2015; Östling 2015). In fact, in the process, it is not uncommon that words take the shape of a different kind of materiality.

The enormous impact that different forms of intertwined media nowadays have on society is effectively captured in the concept of mediatization (see Lundby 2009, Hjarvard 2013). Another line of inquiry, perhaps with still greater relevance for this particular article, is the idea of the folklorescue as an ongoing intertextual relation, characterised by both strategic creativity and fuzzy allusions, that is taking place between folklore and popular culture (Foster \& Talbot 2016).

\section{The Excerpt Collection at the Nordic Museum}

The museum's excerpt collection consists of anything between five hundred thousand and one million catalogue cards (af Klintberg 2010b:214; Gustavsson \& Palmenfelt 2017:410) sorted under carefully specified headings and collected in two separate card catalogues. These are the topographic and subject-oriented (or more correctly: keyword-oriented) collections. As each individual card in the two collections contains data on both the actual folklore substance as well as the geographic domicile (parish), the collections are constructed so as to constantly refer to each other. Thus, the museum is in possession of two complete sets of transcripts of highly sought after material from collections, records and overviews of folk memory relating to customs and beliefs. With reference to the tutorials on 
YouTube, by vlogger Therese Lindgren, we can pick a card from the collection that recapitulate a meeting with the Sea Queen:

Bohus County Tegneby Parish V. 429:8

One morning, a man who lived at the far end of Tånge Sound-I don't know if it was on Lyr Island or on the Mollösund side-went fishing. The weather was intensely beautiful. Then he caught sight of a lovely lass sitting beside the water combing her hair. Her long hair shone like gold. As he rowed close to take a better look at her, she disappeared. Just then, the weather took such a turn for the worse that he was forced to head for land. It was the Sea Queen.

C-M Bergstrand: Gammalt från Orust (Old Tales from Orust), 1962, p 13. Disc. Karl Johansson 1920, Torp, Tegneby. Translated excerpt, Nordic Museum Folklore Collection.

This is knowledge that was once considered so important that great pains were taken to collect and preserve it for posterity. The desire to search through regions and landscapes for the surviving evidence of ancient beliefs has given rise to expeditions all over the nation, influenced the dispatched researchers' choice of questions and formed the basis for large numbers of scholarly publications (cf. Nylund Skog's article in this issue). Therefore, the topographic and subject-oriented collections are at once the result of and incentive to a certain kind of knowledge primarily about preindustrial society. In this sense, the excerpts have contributed to the creation and maintenance of both academic and museological careers. Before going any further with these kinds of conclusions, there is, however, reason to highlight some basic features of the collection's genesis and lines of origin. Namely, that means first presenting the historical setting of the collection, and secondly introducing the museum's use of so-called questionnaires.

The history of the two-part excerpt collection at the Nordic Museum extends back to the early twentieth century. However, even earlier chroniclers such as Gunnar Olof Hyltén-Cavallius and Per Arvid Säfve were already creating private collections of their own and others' fairy tales, customs and colloquialisms (see, for example, Gustavsson \& Palmenfelt 2017). It should also be noted that, at the end of the nineteenth century, the founder of the Nordic Museum, Artur Hazelius, had himself purchased an early collection of excerpts known as the Wallman Collection. In 1907, Nils Edvard Hammarstedt was appointed as the first director of the Archive for Swedish Folk Beliefs and Customs (from 1917 onwards, reconstituted as the Archive for Swedish Folk Knowledge) at the Nordic Museum. Today, the name Folklore Archive is used. The ambition to build a national central folklore archive was largely Hammarstedt's. On his retirement in 1930, the excerpt 
collection included some 30000 items. However, with the establishment of the Hammarstedt Archive at the Nordic Museum, the organisation's conditions were changed at a stroke.

The idea, introduced by Hammarstedt and followed up by his successors, was as simple as it was effective, and it all comes down to disintegration, systematisation, and reintegration. A thorough review of the older collections and sources made it possible to isolate individual motifs from the records, which could then be recorded on separate cards that were sorted into a single gigantic catalogue. Keywords on catalogue cards could then be successively supplemented with new transcribed notes from previous records and research expeditions. For obvious reasons, it was a time-consuming task. By the mid-twentieth century, Carl-Herman Tillhagen, a later director of the Nordic Museum's Folklore Collection, had succeeded in obtaining public funds for a complete review of the archive's handwritten folkloric material relating to folk poetry, beliefs and customs. As many as 20 project workers, many of them Baltic refugees from the Second World War, were then kept busy for several decades with the enormous task of completing the excerpt collection. It was also Tillhagen who introduced the previously mentioned dual cataloguing of the folkloric material into a subject archive (or keyword register) and an equivalent topographic archive (af Klintberg 2010b).

Historical overviews of research often underline how, during the first half of the twentieth century, the discipline of Swedish ethnology (previously folk life studies) grew from an intimate collaboration with the Nordic Museum (see, for example, Hellspong 1993; Nilsson 1996, 2004; Gustavsson 2014). Even up until the publication of Åke Daun's licentiate thesis Upp till kamp i Båtskärnäs in 1969, the museum had been, together with the institutes of folklore in Lund, Gothenburg and Uppsala, a disciplinary hub for major research projects, as folklorists and folk life researchers took on the gigantic task of collecting and documenting the consequences of modernity for rapidly declining rural communities (cf. Lilja 1996; Löfgren 1996; Nilsson 2004; Skott 2008). Throughout this period, questionnaires were an important tool for the museum's staff as a method for collecting, following up and charting. They have continued to be so, even if with a view to obtain different knowledge.

That questionnaires have been so crucial to vital parts of the Nordic Museum's knowledge production for such a long period of time means that they have been the subject of a large number of intradisciplinary studies and surveys. We therefore have a fairly good idea of the process by which the material was gathered: by a paid staff of local informants to whom were sent lists of questions and topics that the museum wanted to know more about. Those "local informants" were 
ordinary people who occupied a position with a certain cultural capital within the community. Their task was to make enquiries regarding conditions in earlier times by contacting those in the community with reliable memories. The answers to the predetermined questions were then sent back to the museum, where they were transformed into academic descriptions, reports and conclusions.

This included hard work by the museum staff as reports submitted by the informants from their own local area were combed over to uncover individual assertions regarding forest nymphs, mermaids, mylings and whatever else might emerge. However, as stated previously, the questionnaires were not the only source of submissions for the museum's excerpt collection. It was the already established working method with regard to excerpts that was transferred to the questionnaires when they were first used at the museum in 1928. Consequently, the catalogue cards in the museum bear witness to a parallel (and in some cases considerably older) collection, consisting of notes by museum staff relating to general proof of whatever phenomena those representatives of the then frontline of research considered important to document. To a large extent, these could be categorised as belief and custom, which earlier folklore researchers-who were rooted in nineteenth-century Romantic language and dialect research-perceived as being closely related to antique and prehistoric belief systems and preserved in the national folk spirit (cf. Nilsson 1996; Salomonsson 2003, Engman 2015). In this cumulative research paradigm, where layer was piled upon layer, any additional data and observations were welcomed as an increase to the already collected mass. The scrutiny was, in search of usable information, extended to previous collections, newspapers, printed tales and publications by other researchers and other donated excerpt collections. These items were incorporated into the museum's ever-expanding knowledge bank in the form of additional catalogue cards. The task of the excerpts, the motivation for their very existence and justification for this extensive writing process, was to render already collected material accessible for diverse academic purposes.

The early 1960s saw a departure in the design and use of questionnaires (cf. Larsson's article in this issue). Local informants and specific respondents were no longer sought out by the museum. The intermediary disappeared in favour of stories taken directly from people's own experiences. This is a well-known shift in focus and method, carefully described in the literature (see Nilsson 2003; Salomonsson 2003, Westergren 2003, cf. Lilja 2016). Less consideration has been given to the part of the process in which the individual answers on each questionnaire were copied down, cut into smaller parts, sorted under the double entries of subject and parish, and saved as excerpts in the museum's collection. Although the lack of wider context that arose regarding these fragments of the original responses has been addressed, the issue of how these rewritten and 
isolated notes were actually used and utilised in the existing research environment has mostly flown beneath the radar (however, see Frykman 1988, Klein 2003, 2010; Löfgren 2013; also Nylund Skog this issue).

Thus, the novelty of the museum's excerpt collection was not that it concentrated a large number of previously dispersed collections in the same place; its significant contribution was rather in the overview it afforded. The excerpt collection created clarity in what otherwise threatened to remain just an unsorted mass of gathered material. As Orvar Löfgren (2013) emphasises, the excerpt collection as a general phenomenon can be understood as a mechanical technology for achieving searchability in large amounts of material. In modern terminology, he continues, the collection can be likened to an analogue search engine.

However, in the days when the Nordic Museum's excerpt collection was more regularly used by researchers, students and museum staff, it also did something else; by cutting up and redirecting the rich source material, the searchable catalogue marked out the direction for future research. Once the excerpt collection was in place, with all of its possibilities for strategic comparison and well-chosen insights, it was simultaneously a strong advocate of its own paradigmatic logic (cf. Svanberg 2008). More than anything else then, the excerpt collection was an academic device crying out to be used, and that also applies for those collections at the museum that were oriented towards findings of material culture. Markus Krajewski suggests that the card index should be regarded as a "paper machine" (2011:7). It is, so to speak, a machine built up by a large amount of single paper slips (or excerpts). The idea of the Nordic Museum's excerpt collection as a research machine underscores, in a similar but not identical way, the productive forces of the collection.

\section{The Excerpt Collection: From Historic Layers to Present day Historiography}

Today the same collection of diverse assertions regarding previous folklore, customs and beliefs has very much ceased to uphold this prominent status in the discipline. With their registry and their many cards and drawers, the two excerpt collections at the Nordic Museum represent a distinct landmark in a disciplinary landscape that, over time, has been drained of both people and activity (cf. Löfgren 2013). Which is, of course, not to say that they are completely deserted or out of use. You can still find some activities going on around the drawers. Nevertheless, today's ethnologists and folklorists seldom choose to utilise the ingresses into the world of ancient folk beliefs that lie hidden in this archive 
of folk memory. Perhaps more importantly, when it does happen, their gaze is usually directed towards the disciplinary conditions, assumptions and practices that once produced the collections (see, for example, Palmenfelt 1993; Lilja 1996, 1999; Nilsson 1996; Nordström 2002; cf. Skott 2008). Unlike at the time when the material was originally gathered and systematised, the value of the excerpts to present-day researchers is not as a source of older layers of folklore or folk memory; rather, the collection has been reduced to sediment and remains. It has become one historic layer comprised of previous researchers' academic ambitions and forms of knowledge.

Over recent decades, there have also been lively discussions as to the value and usefulness of these previously collected sources. However, in these analyses, this folkloric material generally figures as an example of the very idea of a folk tradition, rather than as something that contained the very existence of such a tradition. Thus when this older material is used these days, it is therefore typically viewed not as a research tool to sort out and reveal life forms on the verge of extinction, but rather as a relic that can tell us about the earlier assumptions that motivated the museum's actions and influenced the gatherings of collections. This is something entirely different from the older folklorists' understanding of the collected material as a valuable key to these still lingering folk memories. At the present time, the Nordic Museum's Folklore Collection, including the excerpts, tells us more about those asking the questions than those supplying the information. In other words, there has been a clear shift from answer to question -from the informant to the museum and researcher, and from an interest in the contents of the collection-to a focus on the conditions under which it was created and organised (Österman 1991; Richette 2003; Klein 2003; Nilsson 2004).

In summary, the excerpt collection at the Nordic Museum, which for decades upheld a status as a prominent resource for folk memory/folklife research and later ethnology, has been subjected to a process of academic rejection. The same knowledge that once appeared to be of great interest for the discipline is now considered dubious (for similar research regarding how previous fundamental knowledge within the discipline has been embraced, abandoned and contested over time, see Löfgren 1988, 1993:76; Skott 2010:76; Skott 2014; Gustavsson 2014:203; Nystrand von Unge 2019). It is as if neither the museum nor the discipline itself really want to acknowledge the grand scholarly project that once produced the countless catalogue cards, other than as objects for the museum's and the discipline's own historiography.

Of course, this gradual rejection of the excerpt collection from the discipline's mainstream activities can be understood in relation to the already introduced paradigm shift in methodology and preferred knowledge in ethnological research. However, it is more than that. As Orvar Löfgren (1996) subsequently confirmed, 
at the end of the 1960s it was important for the young, radical ethnologists of the period to distance themselves from their predecessors' deeds and motivations. Faced with the disciplines' historical tradition, it was necessary for the next-generation academics to shine a spotlight on the prevailing conditions of the present day. The Nordic Museum's excerpt collection was therefore drawn into a game of contrasting the past and future of such research, which was essentially a matter of creating an epistemological distance from the old. Just like The Swedish Atlas of Folk Culture (Erixon, ed. 1957), to this younger generation, the excerpt collection stood as a monument to the futile efforts of previous generations.

By definition, the frontline of research must be moved if an academic discipline is to remain relevant to its practitioners. This applies to a significant degree to the displacement in ethnology that many have attempted to place in this formative period. Like a troll cracking in the sunlight, the paradigm to which the excerpts gave expression (and themselves contributed to maintaining) could not withstand the demands for a new orientation in the discipline, as formulated by the new generation of ethnologists. In brief, that which Löfgren and other commentators conjure up is thus a picture of a once vital research tradition gradually being crushed beneath its own weight.

\section{To Storytellers and Collectors with Gratitude}

But what happens to the museum's excerpt collection when, over time, the subject's frontline creeps forward along different lines? Instead of being emptied of substance, the excerpt collection still remains important and relevant, although for a more limited group of people in comparison to its heyday. Admittedly, the academic aura of both the excerpts and the excerpt collection have been brought down to earth with a bump; however, this was not sufficient to wipe out in a single blow their status as valuable for learning and a receptacle of coveted knowledge. There is a straightforward explanation as to why this did not happen; quite simply, far too many people had invested far too much in the excerpts for them to be allowed to fail.

In Latourian language, the Nordic Museum's excerpt collection can be viewed as a blackboxed method or scientific practice that with time was drawn into the light, duly reviled and finally declared inadequate. With all of their individual catalogue cards, the large cabinets in the ground floor of the museum contain a story about how academic research is developed by new paradigms and schools of thought following on from the old. It is not unusual for new standard-bearers to feel a need to break new ground by clearly distancing themselves from their predecessors and their supposedly inadequate methods or pedantic knowledge goals (cf. Kuhn 1979). Nevertheless, if one overlooks the paradigmatic shift in the 
organisation of ethnological knowledge, and instead focuses on what has happened to the older learnings, that is, on the continuing circulation of knowledge, other conditions are revealed.

As ethnologists were presented with new questions, methods and theories with which to engage, a vacuum was also created around the excerpt collection. This was an emptiness simply waiting to be filled by other stakeholders (cf. Skott 2014). Subsequently, as ethnologists have moved on to other academic hunting grounds, it has been possible to integrate the excerpts into other knowledge projects. This is partly because other disciplines have not lived through ethnology's radical break with the past and have therefore continued to benefit from older findings in a different way. Even more clearly, it is also because this older learning has been incorporated into various types of less academic writing, aimed at a broader public, and fictionalised narratives.

This is where Therese Lindgren's tutorials enter the picture. On posting her fifth and final video on YouTube, Lindgren follows her clip about the tree sprite with a brief comment aimed at her followers. In this comment, she reveals the name of the book on folklore that she repeatedly refers to, Nordiska Väsen (2013) by Johan Egerkrans. This is the source of her voiceovers, with some editing of the original text on her part, that explain the folklore behind the various creatures. But from where has author and illustrator Egerkrans obtained his information?

In the book's unnumbered afterword, Egerkrans thanks a number of people for their help in realising the book and presents a vast number of different creatures from the Nordic region, using both text and his own spectacular illustrations. Among the editors and encouraging friends, one particular thank-you stands out. Here, he expresses his gratitude to,

All of the farmers, farmers' wives, farm labourers, peddlers, milk maids, sharecroppers, soldiers, parish constables, hunched old men and wise old women from long ago who shared all of these fantastic tales, and to all of the dedicated souls who collected them.

However, during the writing of the book, Egerkrans found no need to visit the excerpt collection at the Nordic Museum, with all its' material reminders of those long-gone storytellers and collectors. In a special thanks to the staff of Stockholm Public Library, he explains that the stories presented are based on already published works. On the final page, a number of familiar names appear among the references. The two names that dominate the literature list are Carl-Herman Tillhagen and Ebbe Schön. Here, in some general reference works and annotated publications from the archive, we find the sources where Egerkrans has been able to gather valuable information for his own book. 
Both Tillhagen and Schön have a past as directors of the Nordic Museum Folklore Collection and, as the above list demonstrates, they are also two folklorists whose careers and bibliographies are closely linked to the current excerpt collection. On scanning this literature list, it is therefore possible to state that a direct connection exists that unifies modern-day vlogger Therese Lindgren, author and illustrator Johan Egerkrans, the two head archivists and the Nordic Museum's excerpt collection. Such influences are not always so easy to trace, which is, of course, not to say that they do not exist.

The popular Sweden PAX series of books about the twins Alrik and Viggo Delling in Mariefred, for children in their younger teens, is yet another example of how ancient Nordic folklore is able to find new takers in our own time. The first book was published in 2014 and up to now it has been followed by eight more. All of these books feature a named folkloric creature in a central role: for example, the grim, the mare, the neck, the tilberi or the ghost. The literary form of the collaboration between authors Åsa Larsson and Ingela Korsell and illustrator Henrik Jonsson thus depends on the type of knowledge concerning folkloric characters that has been collected in droves (or rather on small catalogue cards) in the museum's archives. This has been channelled out over subsequent decades in books that bear varying degrees of academic and scientific hallmarks. Among many other recent possible examples of this kind of use and reuse of early findings are the Norwegian film Trolljägaren (2010); the Swedish film Gräns (2018)currently nominated as Sweden's candidate for the 2019 Oscars; books such as Stefan Spjut's Stallo (2012), which takes place in the borderlands between Nordic and Sami mythology (with a dollop of artist John Bauer), and Anders Fager's Swedish Cults (2009). Most recently, Ingela Korsell, one of the two coauthors involved in the PAX project, has presented a new book, Väsenologi (2019) on the same topic. Together with illustrator Reine Rosenberg she describes a wide range of beliefs with references to creatures from the Nordic region. This account also clarifies the fact that collected learning regarding folkloric creatures is now utilised to build careers other than the purely academic ones.

Other proponents have connected with the same material from a quite different angle. As Jonas Engman (2015) has pointed out, the excerpts and folklore archives have also been pulled into contemporary political contexts. When, in their 2015 party programme, the Sweden Democrats pointed to the existence of a "Community of Nordic Peoples", their argument rested on a cultural-heritage rhetoric that was both inclusive and exclusive, having its roots in the previous century's national romanticism and pan-Nordic movement. During the last few years the political uses of this material, to support nationalistic and right-wing agendas, has repeatedly been targeted by Swedish media. This was not least the case when the Sweden Democrats in December 2018 put forward a proposal to 
the Swedish Parliament, that there should be a national institute working for the benefits of adding elements of Nordic mythology, traditions, beliefs, and history to the Swedish gaming culture and products. In their argument, they particularly stated that Sweden's and the Nordic region's nature, mythology and cultural history must be considered a source of great inspiration for this steadily growing industry.

In summary, over the course of time the excerpt collection at the Nordic Museum has not solely functioned as a useful device to generations of researchers. Truly, it has also been a machine that has given rise to researchers. The museum and researchers have produced questionnaires and excerpts; however, once in place in the ordered collection, these excerpts have also produced research, methods, theories, terminology and, not least, researchers and individual careers. As Jonas Frykman confirmed, folklore research's excerpts were for a long time functional elements in a methodological and source-critical paradigm in which researchers and archives constituted "a union in which it was sometimes difficult to tell where the researcher ended and the archival system began" (Frykman 2010:257).

\section{Old Knowledge in new Streams}

As demonstrated above, once understood and utilised as a crucial resource in folklore research, the recorded material is neither abandoned nor forgotten. Rather, by emigrating from the archive's subject-oriented and topographic excerpt collections, it has moved on from a given academic discourse to other academic forums, and in an increasingly popular, and even political, direction. This carefully ordered and systematised archival material, which for more than half a century was a vital part of the Nordic Museum's scholarly endeavours, is nowadays a recurring feature of newspaper reports on the old traditions linked to Easter, Christmas or newcomer Halloween, but it can also be found in other streams and in the hands of new knowledge producers. Academic books and studies are still published in which the author, at least in part, or with new kind of questions, utilises the knowledge represented by the older excerpts. This applies not least to the vigorous research conducted within the framework of the folklore archive. Nevertheless, with a few notable exceptions, such as Jochum Stattin (1984), Malmberg (1991) and Inger Lövkrona (1996), the vast majority of ethnological research has long since chosen to look elsewhere, towards other source material. Accordingly, far from being a significant part of cutting-edge research, which they once were, the collection of excerpts in the Nordic museum has in many respects been tossed away by its own discipline.

This does not mean that the excerpt collection now lacks proponents or supporters. Contrarily, this "forgotten monument" is not quite as abandoned as one might think. The salient point is that it is mostly new visitors who stand flipping 
through the catalogue cards or who absorb the more readily available knowledge produced and published by researchers with long careers within the walls of the museum and archive. Today, it is no longer primarily ethnologists who write from a scholarly horizon on the folklore of, for example, forest nymphs or witchcraft (see Häll 2013; Malmstedt 2018). But still, some interests and stakeholders will not so easily change over time. Within disciplines such as religious history and Nordic languages, the excerpts have never ceased to be scholarly relevant. Moreover, for some people, efforts made and laurels won have stood in the way of the new direction that others have embraced. Among established folklorists and researchers some might consider it, therefore, a better alternative to hold onto the expertise, methods and theoretical points of departure that proved to be a key to previous success.

While the majority of academically active ethnologists have turned their backs on the Nordic Museum's excerpt collection, some of their colleagues remained; having said that, for these individuals too, something has fundamentally changed. The same excerpts that had once been perfectly suitable for achieving recognition for one's research, and that had once corresponded to the very idea of a legitimate material, were now the stuff of writing that found itself somewhat drifting towards a more popular, and less academic, position. Researchers such as Carl-Herman Tillhagen, Ebbe Schön and Jan-Öjvind Swahn can all be associated with an encyclopaedic knowledge rooted in the archive and excerpt collection. However, as the scholarly status of the excerpts plummeted in value, so too did the academic capital of these previously influential specialists. In the archive and extract collection, we can therefore discern the icy wind of a discreet dispute concerning disciplinary methodology, the value of the excerpt collection and, not least, the reputations and legacies of the researchers themselves.

Naturally, this tendency towards a less academic position regarding writing and career need not be considered in this way. Those persons mentioned have all gained a great reputation as experts on Swedish folk beliefs. Representatives of the folkloric field have also been able to combine academic reputation with an extensive, popular authorship. The most obvious examples of this are Ulf Palmenfelt and Bengt af Klintberg. However, this generally involves maintaining separation between the two forms of writing and readerships. Klintberg (1993) has personally stated that in the mid-1980s he chose to leave the ethnology field as he perceived that there was no longer room for the kind of text-oriented and source-oriented folklore expertise that he himself represented.

Eventually, it is also important to emphasise that, unlike the rather context-less extracts, the questionnaires as both material and method have in many respects survived into the present day as an ethnological resource (see, for example Hagström \& Marander-Eklund 2005; Hagström \& Sjöholm 2017). The earlier 
theories that once justified both the design of the questionnaires and the methods of their collecting have been abandoned. However, over time, much of what was found to be irrelevant data by previous generations of researchers has later on come to be considered valuable and useful (Waldetoft 2003:12f, cf. Nilsson 2003:112). Perhaps this shift in perspective most clearly illustrates the rupture with the older paradigm that once generated the subject-oriented and topographic extracts. With the questionaries' there is always the possibility to go back in the archive and search for the whole document that had originally been sent in to the museum, before its presumed legitimate findings were sorted out on the catalogue cards. For the continued use of the excerpt collection as relevant research material per se, there was the added difficulty that the slim information on the excerpts was already the result of a strategic cull of the larger data stream. Any hidden treasures that might have been of interest to later generations of researchers was for the most part exactly what the museum's enormous collection of excerpted transcripts has chosen not to preserve.

\section{The Excerpt as Museological Boomerang}

The Nordic Museum's excerpt collection can be compared to the practice of exhibiting, in the contemporary cultural or natural history museum, a preserved part of an old curiosity cabinet. In the same way that visitors may be both entertained and astonished over the curiosity cabinet's unexpected combinations of artefacts, the excerpt collection becomes both a cautionary and tender reminder of now bygone academic aspirations. Its function within the museum is thereby as an institutional keepsake; a stratification of previous researchers' ambitions and epistemology, gratefully used in the teaching of prospective ethnologists. However, despite the fact that the majority of ethnologists have ceased to ascribe it any specific value, apart from its position as a remnant and historiographic resource, the excerpt collection's accumulated knowledge continues to remain relevant and build careers in other fields.

The excerpt collection, and the knowledge it once represented, may have been relocated to other venues and other stakeholders, but it still occasionally wanders back to what might be considered its museological origins. Almost simultaneously to Therese Lindgren posting her tutorials on YouTube, the Nordic Museum took the initiative of arranging a Swedish National Championship in Cosplay, the Japanese form of costume play in which participants dress up as famous, generally pop-culture, figures. These are often characters taken from manga, computer games or fantasy literature (Winge 2019).

The Nordic Museum's competition was a variant of the same format, but with an added twist. Beginning in autumn 2016, the three finalists selected after 
a national qualifying round were invited to examine the museum's collection, before choosing a character of Nordic folklore to be present on the museum's own stage six months later. Before beginning, at the end of November, the finalists met individually with a number of the Nordic Museum's attendants, librarians and archivists. This was to allow them to familiarise themselves with the archive and artefact collection, so that they could "get to know trolls, forest nymphs, imps, elves, werewolves and other creatures". Later in the day, the finalists were invited to join the public at an open lecture on folkloric creatures given by Ebbe Schön, introduced as "Sweden's leading expert in the field".

The competition received a great deal of attention, even appearing in several items on Swedish television. The winner, Rickard Nilsson, chose to play an ancient mountain troll, with John Bauer's almost century-old illustrations being a clear influence on the make-up, mask and costume. As with Lindgren's introductory tutorials, those interested were able to follow the contestant's trials and tribulations, either through their own channels or via the museum's website and continuously updated blog.

As this event demonstrated, modern-day knowledge of folkloric characters is not confined to YouTube or as an obvious source of inspiration for books and films. On the contrary, it literally comes back to the museum. Neither is the presence of trolls and these other creatures at the museum's cosplay event a coincidence. This specific invitation reflects the museum's changing radius of action over time. Unlike the period in which the older folklore material was collected and made searchable and accessible through the museum's excerpt collection, today's Nordic Museum is less inclined to look exclusively back in time. The former taken for granted historical perspective is now challenged with the assumption that the real excitement might be happening right now, in our own day and age. As trolls and other creatures from the vast Nordic folklore fauna in a clearly folklorescque way have nowadays become a manifest element of popular culture, and thereby part of the everyday lives of young people and adults alike (cf. Foster \& Tolbert 2016, red.; see also Wall 2017), it is hardly remarkable that these costumed figures are also invited into the great hall of the museum.

The actual link to how these re-enacted characters are presented in the excerpt collection's catalogue cards can sometimes appear more than a little weak; however, from the museum's perspective, this is of little consequence. This is because the museum's widened scope of action has brought with it a different view of what can be considered valid knowledge. The old tradition's monumental efforts to gather, sort and preserve the diverse evidence of a disappearing folk culture has been replaced by an attitude towards knowledge and culture that places a premium on culture as process, performance and hybridisation. In this sense, there no longer exists any authentic expression of a given folk culture to 
collect and keep in drawers. What does exist, however, are occasions on which groups or individuals make use of the past's lingering repertoire of artefacts and beliefs to try on identities in the present. Naturally, the Nordic Museum remains a suitable stage for this kind of creativity.

Paradoxically, this also means that the world of popular beliefs that was once collected under the supervision of the museum's researchers is now also returning to the house of the father. Thus, once again it is true that when archival knowledge is used and reused it is also somehow changed (Gustavsson 2018, see also Östling 2015). Finally, after having spent so long a time under the radar of both the museum and the discipline of ethnology, this folklore material has gone through a process of pop-cultural revitalisation that has once again made it museologically desirable. When the museum opens its doors to a popular costume competition, it is therefore also keen to acquire the outfits of the three finalists. At the time of writing, no such acquisition has been made nor, for the purposes of our discussion, is this necessary. The salient point is the museum's stated ambition to inflate its collections with the costumes from the 2017 cosplay championship, in which participants interpreted the folk beliefs that have found their way out along various paths from the museum's at once dormant and highly active excerpt collection.

\section{A Network in Dissolution}

The excerpts in the Nordic Museum's Folklore Collection have a history that stretches back to the nineteenth century. Even if the number of catalogue cards will long remain the same, it must be affirmed that this is very much a story in the making; it is still being added to. The roots of the collection do not solely stretch down into the past, but also out into our own time-and nothing suggests that these connections will cease to work their way outwards in future. However, it remains an open question as to whether future ethnologists will make their peace with the excerpt collection. Perhaps they will; perhaps the collection will open itself up to new, vital fields and research questions. Something that suggests that this is the case is that several Swedish folklore archives have come together in a single digital platform to make available their own collections. Then again, maybe the excerpts will remain so associated with the central issues, methods, theories and research ideals of a previous era that, for many researchers schooled in present day ethnology, they will continue to generate a considerable epistemological fear of contact. This mechanism of rejection has not, however, infected everyone. As we have seen, other disciplines and non-academic stakeholders are not haunted by those severe problems that the ethnologists of the 1960s and 1970s associated with this older perspective, and with the excerpts as its material outcome. 
Consequently, when folk life researchers and ethnologists successively retreated from the field of research that gravitated around the lingering traces of past folk beliefs and customs, of which the excerpt collection constituted such a powerful and productive centre, this field was left free for others to claim.

To the extent that the Nordic Museum's excerpt collection is recognised as a resource by the academic institution that in many ways can be considered its nearest relative, that is, the ethnological environment at Stockholm University, it is nowadays primarily used as support for the teaching of new students. Here, the collection and catalogue cards fulfil a significant role in that a visit to the museum both provides a concrete opportunity for ethnology students to come into contact with their own research history and to acquaint themselves with archival material. A review of the institutions' own theses for the past two decades would, however, show few references to the museum's excerpt collection, something that underlines the reduced importance of the collection as an active and utilised research resource. What is considerably more difficult is to convey to the students an understanding of what a productive research machine the excerpt collection once was. Even if the collection were to get a new lease on life, it is unlikely that it will ever have the same significance. Without doubt, the material can still be used to deepen our understanding of both our own age and other eras. However, the accumulated network of relationships that once linked the excerpts, researchers, academic books and journals, and some scholarly careers to one another has long since fallen apart and faded into history.

Simon Ekström, is associated professor in Ethnology at Stockholm University. He is also part of CEMAS (Centre for Maritime Studies) at the same university. His research has since long been directed towards the production and circulation of different forms of authorized knowledge, often in relation to gender and media. Currently, he is working on a project that focuses on maritime museums as institutions and destinations marked with the presence of human death. Email: simon.ekstrom@etnologi.su.se 


\section{Notes}

1https://www.youtube.com/watch?v=vT9ZIluwY4s

2These collections were often established by individual researchers and museum staff. As an example museum official Gösta Berg is often mentioned as someone with a very large personal excerpt collection, the industrious use of which allowed him to achieve a bibliography of almost a thousand publications (Myrdal 2010). Excerpts, of all kind, could also be used as private resources to be traded, or given as gifts, to colleagues. 3Such spiritual artefacts might for example include a belief, legend or custom, although it could also be an individual fairy tale if this could be tracked in time and space.

4 Bo G. Nilsson places the change from evolutionism to diffusionism in the Swedish exploration of folk culture to somewhere around 1920 (2004:85ff).

5 For further information about Hammarstedt, see Nilsson 2004:93; af Klintberg 2010a (with additional reference to Bringeus 2006:106).

6 Questionnaires as a practical research resource are discussed in detail in two anthologies: Frågelist och berättarglädje. Om frågelistor som forskningsmetod och folklig genre (Nilsson, Waldetoft \& Westergren, eds. 2003), and Frågelistan som källa och metod (Hagström \& Marander-Eklund, eds. 2005).

7 In Paper Machines, About Cards and Catalogs, 1548-1929 Krajewski states, "The possibility of rearranging its elements makes the card index a machine: if changing the position of a slip of paper and subsequently introducing it in another place means shifting other index cards, this process can be described as a chained mechanism" (2011:7).

8 The change of name within the discipline was discussed in detail by Nils-Arvid Bringeus in 1988 (with specific reference to the chair at Lund University).

9 Elsewhere, Jonas Frykman (2010) has pointed to the possibility of discussing the use of excerpts and archives based on Bruno Latour's Actor-Network-Theory (ANT). Orvar Löfgren (2013) thinks along similar lines when he mentions archive material as coauthors and stakeholders. See also Matts Lindström (2017) regarding microfilm and Charlie Järpvall (2016) on copier paper.

10 https://www.youtube.com/watch?v=1_JXUtOVQxM

11 Among the listed titles are: Erotiska väsen; Folktro från förr; Folktrons ABC; Skepnader i skymningen-möten med folktrons väsen; Svensk folktro A till Ö-hur vi tänkt, trott och trollat; Troll och människa-gammal svensk folktro; Älvor, troll och talande trädfolktro om svensk natur (by Schön), as well as: Barnet i folktron -tillblivelse, födelse och fostran; Fåglarna i folktron; Vattnets folktro-sägen och berättelser kring bäckar, älvar, sjöar och hav (by Tillhagen).

12 https://www.riksdagen.se/sv/dokument-lagar/dokument/motion/ H602644, see also https://www.riksdagen.se/sv/dokument-lagar/dokument/motion/spel-som-kulturform H4022194

13 Staffan Bergwik has stressed that knowledge is never individual but rather systemic. Therefore, he argues, a science professor must be understood in relation to 
a functioning network of assistants, buildings, dinner parties, her/his own and other people's publications and, yes, even the professor's pen and desk, if they are to achieve a successful academic career (2016: 97ff, 126, see also Gustavsson 2014:192ff).

14 Source: $\underline{\text { https://www.nordiskamuseet.se/blogg/cosplay }}$

15 Source: https://www.nordiskamuseet.se/kalendarium/foredrag-lar-kanna-folktrons-vasen

16 The two remaining finalists chose to play a mountain nymph and forest nymph respectively.

17 As stated in the competition entry form: "It is desirable that, within one year of the completion of the competition, participants donate their costumes to the Nordic Museum's costume collection to be preserved for posterity (NB, this entirely voluntary)". Source: https://www.nordiskamuseet.se/artiklar/tavlingsregler-cosplay 18 These different perspectives, that is to say, the lingering and the ongoing, respectively, can of course be seen as two sides of the same coin.

19 See the map at: http://www.sprakochfolkminnen.se/om-oss/kartor/sagenkartan. $\underline{\mathrm{html} \# / \text { places }}$

20 It should though be emphasised that in other ethnology institutions, such as in Lund, such a review would probably yield a different result. Here, collaboration with the university's own folklore archive has demonstrated considerably more vitality over time.

21 As stated earlier, perhaps further achievement on the field will prove this rather gloomy prediction wrong. There are actually some promising signs that the excerpts have gained renewed interest from scholars within the discipline of folklore studies (se for instance Harjunen 2017).

\section{References}

\section{Internet Sources}

https://www.youtube.com/watch?v=vJ9ZIluwY4s (visited 16.01.2018)

https://www.youtube.com/watch?v=1 JXUtOVQxM (visited 16.01.2018)

https://www.riksdagen.se/sv/dokument-lagar/dokument/motion/_H602644 (visited 29.08.2019)

https://www.riksdagen.se/sv/dokument-lagar/dokument/motion/spel-som-kulturform H4022194 (visited 29.08.2019)

Source: https://www.nordiskamuseet.se/blogg/cosplay (visited 21.02.2018)

Source:https://www.nordiskamuseet.se/kalendarium/foredrag-lar-kanna-folktrons-vasen (visited 23.01.2018)

https://www.nordiskamuseet.se/artiklar/tavlingsregler-cosplay (visited 21.02.2018).

http://www.sprakochfolkminnen.se/om-oss/kartor/sagenkartan.html\#/places (visited 21.08.2018) 


\section{Culture Unbound}

Journal of Current Cultural Research

\section{Literature}

Atlas över svensk folkkultur. 1, Materiell och social kultur. Åke Campell \& Sigurd Erixon (eds.) (1957). Uppsala: Lundequistska bokhandeln.

Atlas över svensk folkkultur. 2, Sägen, tro och högtidssed. Åke Campbell \& Åsa Nyman (eds.) (1976). Uppsala: Lundequistska bokhandeln.

Bergwik, Staffan (2016): Kunskapens osynliga scener. Vetenskapshistorier 1900-1950. Göteborg/Stockholm: Makadam.

Bringeus, Nils-Arvid (1988): "Lärostolen och ämnesbeteckningen". Nils-Arvid Bringeus (ed.): Folklivsarkivet $i$ Lund 1913-1988. En festskrift till 75-årsjubileet. Lund: Folklivsarkivet, 123-143.

Bringeus, Nils-Arvid (2006): Carl Wilhelm von Sydow som folklorist. Uppsala: Kungl. Gustav Adolfs akademien för svensk folkkultur.

Bolter, Jay David \& Richard Grusin (1999): Remediation. Understanding New Media. Cambridge, Mass.: MIT Press.

Burke, Peter (2016): What is the History of Knowledge? Cambridge: Polity Press.

Daun, Åke (1969): Upp till kamp i Båtskärsnäs. En etnologisk studie av ett samhälle inför industrinedläggelse. Uppsala: Verdandi.

Egerkrans, Johan (2013): Nordiska väsen. Stockholm: B. Wahlström.

Engman, Jonas (2015): "Folklivsarkivens ideologiska och politiska kontexter. Neonationalism och kulturarvets popularisering". Marianne Larsson et al. (eds.): Utkanter och marginaler. 31 texter om kulturhistoria. Stockholm: Nordiska museet, 20-27.

Fager, Anders (2009): Svenska kulter. Göteborg: Man av skugga.

Foster, Michael Dylan \& Jeffrey Tolbert (eds.) (2016): The Folkloresque. Reframing Folklore in a Popular Culture World. Logan: Utah State University Press.

Frykman, Jonas (1988): "Folklivsarkivet, frågelistorna och forskningen". Nils-Arvid Bringeus (ed.): Folklivsarkivet i Lund 1913-1988. En festskrift till 75-årsjubileet. Lund: Folklivsarkivet, 91-107.

Frykman, Jonas (2010): "Brita Egardt (1916-1990)". Mats Hellspong \& Fredrik Skott (eds.): Svenska etnologer och folklorister. Uppsala: Kungl. Gustav Adolfs akademien för svensk folkkultur, 253-260.

Frågelist och berättarglädje. Om frågelistor som forskningsmetod och folklig genre. Bo G. Nilsson, Dan Waldetoft \& Christina Westergren (eds.) (2003). Stockholm: Nordiska museet.

Frågelistan som källa och metod. Charlotte Hagström \& Lena Marander-Eklund (eds.) (2005). Lund: Studentlitteratur.

Gustavsson, Karin (2014): Expeditioner $i$ det förflutna. Etnologiska fältarbeten och försvinnande allmogekultur under 1900-talets början. Stockholm: Nordiska museet. Diss.

Gustavsson, Karin (2018): “Kulturforskningar i Tornedalen. Fältarbete och resultat från 1922 års Norrbottensexpedition”. Svenska landsmål och svenskt folkliv, 2017, 27-53.

Gustavsson, Lotten Reinius (2013): "Kongobussen kommer! Den etnografiska vandringsutställningen som ett missionerande medium". Lotten Gustafsson Reinius, Ylva Habel \& Solveig Jülich (eds.): Bussen är budskapet. Perspektiv på mobilitet, materialitet och modernitet. Stockholm: Kungliga biblioteket, 29-53.

Gustavsson, Per \& Ulf Palmenfelt (2017): Insamlarna. Folksagan i Sverige 1. Stockholm: Carlsson.

Harjunen, Catarina (2017): "Queera möten i finlandssvenska folksägner". Laboratorium för folk och kultur, 2017:2.

Hagström, Charlotte \& Carina Sjöholm (2017): "Nya frågor till gamla svar. Frågelistor som kulturhistorisk källa”. Fredrik Nilsson \& Lars-Eric Jönsson (eds.): Kulturhistoria. En etnologisk metodbok. Lund: Lunds universitet, 137-154. 


\section{Culture Unbound}

Hellspong, Mats (2003): "Den glansfulla Sigurd Erixon-epoken: den Hallwylska professuren 1934-1955". Mats Hellspong (ed.): Lusthusporten. En forskningsinstitution och dess framväxt 1918-1993. Festskrift till den Hallwylska professuren $i$ folklivsforskning $i$ Stockholm vid dess 75-årsjubileum. Stockholm: Nordiska museet, 52-73.

Hjarvard, Stig (2013): The Mediatization of Culture and Society. London: Routledge.

Häll, Mikael (2013): Skogsrået, näcken och djävulen. Erotiska naturväsen och demonisk sexualitet i 1600- och 1700-talens Sverige. Lund: Lunds universitet. Diss.

Jülich, Solveig (2015). "The Making of a Best-Selling Book on Reproduction: Lennart Nilsson's 'A Child Is Born'”. Bulletin of The History of Medicine, 2015:3, 491-526.

Järpvall, Charlie (2016): Pappersarbete. Formandet av och föreställningar om kontorspapper som medium. Lund: Lunds universitet. Diss

Klein, Barbro (2003): "Nm 223 Personlig hygien. Reflektioner kring frågelistor, meddelarsvar och vetenskap". Bo G. Nilsson, Dan Waldetoft \& Christina Westergren (eds.): Frågelist och berättarglädje. Om frågelistor som forskningsmetod och folklig genre. Stockholm: Nordiska museet, 69-88.

Klintberg, Bengt af (1993): "En folklorists hågkomster från Lusthusporten”. Mats Hellspong (ed.): Lusthusporten. En forskningsinstitution och dess framväxt 1918-1993. Festskrift till den Hallwylska professuren $i$ folklivsforskning $i$ Stockholm vid dess 75-årsjubileum. Stockholm: Nordiska museet, 150-170.

Klintberg, Bengt af (2010a): "Nils Edvard Hammarstedt (1861-1939)". Mats Hellspong \& Fredrik Skott (eds.): Svenska etnologer och folklorister. Uppsala: Kungl. Gustav Adolfs akademien för svensk folkkultur, 33-40.

Klintberg, Bengt af (2010b): "Carl-Herman Tillhagen (1906-2002)". Mats Hellspong \& Fredrik Skott (eds.): Svenska etnologer och folklorister. Uppsala: Kungl. Gustav Adolfs akademien för svensk folkkultur, 211-218.

Krajewski, Markus (2011): Paper Machines. About Cards and Catalogs 1548-1929. Cambridge/Mass.: MIT Press.

Korsell, Ingela (2019): Väsenologi. En lättbegriplig vetenskapligt grundad faktabok om väsen i nordisk folktro. Stockholm: Natur och Kultur.

Kuhn, Thomas (1979): De vetenskapliga revolutionernas struktur. Lund: Doxa.

Lilja, Agneta (1996): Föreställningen om den ideala uppteckningen. En studie av idé och praktik vid traditionssamlande arkiv: ett exempel från Uppsala 1914-1945. Uppsala: Uppsala universitet. Diss

Lilja, Agneta (1999): "Kollektiva beskrivningar och individuella berättelser". Magnus Bergquist \& Birgitta Svensson (eds.): Metod och minne. Etnologiska tolkningar och rekonstruktioner. Lund: Studentlitteratur, 115-134.

Lindström, Matts (2017): Drömmar om det minsta. Mikrofilm, överflöd och brist: 1900-1970. Stockholm: Stockholms universitet. Diss

Lundby, Knut (ed.), (2009): Mediatization. Concept, Changes, Consequences. New York: Lang.

Löfgren, Orvar(1988): “Ettämne väljer väg”. Nils-Arvid bringeus (ed.): Folklivsarkivet $i$ Lund 1913-1988. En festskrift till 75-ärsjubileet. Lund: Folklivsarkivet, 144-166.

Löfgren, Orvar (1993): "På John Granlunds tid: Lusthusporten 1955-1969”. Mats Hellspong (ed.): Lusthusporten. En forskningsinstitution och dess framväxt 1918-1993. Festskrift till den Hallwylska professuren $i$ folklivsforskning $i$ Stockholm vid dess 75-årsjubileum. Stockholm: Nordiska museet, 74-107.

Löfgren, Orvar (1996): "Sakletarna. Om det materiellas betydelse i etnologin". Åke Daun (ed.): Ting, kultur, mening. Stockholm: Nordiska museet, 137-160.

Löfgren, Orvar (2013): "Arkivlådan. Konsten att bygga en analog sökmotor". Charlotte Hagström, Göran Sjögård \& Carina Sjöholm (eds.): Folklivsarkivet $i$ Lund 100 år. Lund: Lunds universitet, 30-38.

Lövkrona. Inger (1996): "Suktande pigor och finurliga drängar". Britta Lundgren, Inger Lövkrona \& Lena Martinsson (eds.): Atskilja och förena. Etnologiskforskning om betydelser av kön. Stockholm: Carlsson, 87-182. 


\section{Culture Unbound}

Journal of Current Cultural Research

Malmberg, Denise (1991): Skammens röda blomma. Menstruationen och den menstruerande kvinnan i svensk tradition. Uppsala: Uppsala universitet. Diss

Malmstedt, Göran (2018): En förtrollad värld. Förmoderna föreställningar och bohuslänska trolldomsprocesser 1669-1672. Lund: Nordic Acadmic Press.

Myrdal, Janken (2010): "Gösta Berg (1903-1993)". Mats Hellspong \& Fredrik Skott (eds.): Svenska etnologer och folklorister. Uppsala: Kungl. Gustav Adolfs akademien för svensk folkkultur, 187-184.

Nilsson, Bo G. (1996): Folkhemmets arbetarminnen. En undersökning av de historiska och diskursiva villkoren för svenska arbetares levnadsskildringar. Stockholm: Nordiska museet. Diss.

Nilsson, Bo G. (2003): "Frågor, svar och vad mer?" Bo G. Nilsson, Dan Waldetoft \& Christina Westergren (eds.): Frågelist och berättarglädje. Om frågelistor som forskningsmetod och folklig genre. Stockholm: Nordiska museet, 105-116.

Nilsson, Bo G. (2004): "Framtidens salt: om museernas och folklivsforskarnas bidrag till folkhemsbygget". Bo G. Nilsson, Cecilia Hammarlund-Larsson \& Eva Silvén (eds.): Samhällsideal och framtidsbilder. Perspektiv på Nordiska museets dokumentation och forskning. Stockholm: Nordiska museet/Carlsson, 67-139.

Nordström, Annika (2002): Syskonen Svensson - sångerna och livet. En folklig repertoar i 1900-talets Göteborg. Göteborg: Göteborgs universitet. Diss.

Nystrand von Unge, Elin (2019): Samla samtid. Insamlingspraktiker och temporalitet på kulturhistoriska museer. Stockholm: Vulkan. Diss.

Palmenfelt, Ulf(1993): Per Arvid Säves möten med människor och sägner. Stockholm: Carlsson. Diss.

PAX I-X (2019): Ingela Korsell, Åsa Larsson \& Henrik Jonsson. Stockholm: Bonnier Carlsen.

Richette, Christian (2003): "Frågelistan. Ett kontextkritiskt perspektiv". Bo G. Nilsson, Dan Waldetoft \& Christina Westergren (eds.): Frågelist och berättarglädje. Om frågelistor som forskningsmetod och folklig genre. Stockholm: Nordiska museet, 117-130.

Salomonsson, Anders (2003): "Folklivsarkivet och frågelistorna". Bo G. Nilsson, Dan Waldetoft \& Christina Westergren (eds.): Frågelist och berättarglädje. Om frågelistor som forskningsmetod och folklig genre. Stockholm: Nordiska museet, 89-100.

Secord, James (2004): “Knowledge in Transit”. Isis, 2004:4, 654-672.

Skott, Fredrik (2008): Folkets minnen. Traditionsinsamling $i$ idé och praktik 1919-1964. Göteborg: Göteborgs universitet. Diss

Skott, Fredrik (2010): "Hilding Celander (1876-1965)". Mats Hellspong \& Fredrik Skott (eds.): Svenska etnologer och folklorister. Uppsala: Kungl. Gustav Adolfs akademien för svensk folkkultur, 69-78.

Skott, Fredrik (2014): "Folkloristiken och folkminnesarkiven". Rig, 2014:1, 32-36.

Spjut, Stefan (2012): Stallo. Stockholm: Bonnier.

Stattin, Jochum (1984): Näcken. Spelman eller gränsvakt. Lund: Lunds universitet. Diss.

Fredrik Svanberg (2008): "Museum Narration and the Collecting Machine: Or how Collections Make Collectors". Peter Aronsson \& Andreas Nyblom (eds.): Comparing: National Museums, Territories, Nation-Building and Change. NaMu IV. Linköping, University, Norrköping, Sweden 18-20 February 2008. Conference Proceedings, 175-182.

Svensson, Sigfrid (1942): Bygd och yttervärld. Studier över förhållandet mellan nyheter och tradition. Stockholm: Nordiska museet.

Waldetoft, Dan (2003): "Vad vill vi med våra frågelistor?" Bo G. Nilsson, Dan Waldetoft \& Christina Westergren (eds.): Frågelist och berättarglädje. Om frågelistor som forskningsmetod och folklig genre. Stockholm: Nordiska museet, 9-18. 
Wall, Tora (2017): "Folklore och turism: om bruket av väsen i turistattraktioner". Laboratorium för folk och kultur, 2017:2.

Westergren, Christina (2003): "Meddelare, kvinnor och vanliga människor" Bo G. Nilsson, Dan Waldetoft \& Christina Westergren (eds.): Frågelist och berättarglädje. Om frågelistor som forskningsmetod och folklig genre. Stockholm: Nordiska museet, 17-32.

Winge, Theresa (2019): Costuming Cosplay. Dressing the Imagination. London: Bloomsbury Visual Arts.

Åhrén, Eva Snickare (2004): "Känn dig själv! Om vaxkabinett och anatomiska utställningar". Anders Ekström (ed.): Den mediala vetenskapen. Nora: Nya Doxa, 59-87.

Österman, Annika (1991): Människors egen historia. Om Nordiska museets frågelistverksamhet. Stockholm: Nordiska museet.

Östling, Johan (2015): "Vad är kunskapshistoria?”. Historisk tidskrift, 2015:1, 109-119.

Östling, Johan \& David Larsson Heidenblad (2017): “Cirkulation—ett kunskapshistoriskt nyckelbegrepp". Historisk tidskrift, 2017:2, 269-284. 